\title{
Şanlıurfa İsot Biberinin Pazarlama Kanallarındaki Durum Tespiti: Satıcılar Örneklemesi
}

\author{
Mustafa Hakkı AYDOĞDU1 ${ }^{*}$, Ahmet Ferit ATASOY², M. Emre EREN ${ }^{3}$, Nusret MUTLU \\ ${ }^{1}$ Harran Üniversitesi, Ziraat Fakültesi, Tarım Ekonomisi Bölümü, Şanlıurfa \\ ${ }^{2}$ Harran Üniversitesi, Ziraat Fakültesi, Gıda Mühendisliği Bölümü, Şanlıurfa \\ ${ }^{3}$ Harran Üniversitesi, Teknik Bilimler Meslek Yüksekokulu, Şanlıurfa \\ ${ }^{4}$ Kalkınma Bakanlığı, GAP Bölge Kalkınma İdaresi Başkanlığı, Şanlıurfa \\ *Sorumlu yazar:mhaydogdu@hotmail.com, mhaydogdu@harran.edu.tr
}

\begin{abstract}
Öz
Üreticiler tarafından üretilen malların tüketiciye ulaştırılmasında satıcıların fonksiyonu büyüktür. Satıcılar, pazarlama kanalında ve ekonomik yapının gelişmesinde önemli bir role sahiptirler. Üretim ile tüketimin farklı yerlerde ve zamanlarda yapılmasından dolayı, satıcıların fonksiyonu tarımsal ürünlerin pazarlanmasında daha da önemli hale gelmektedir. Tarımsal alanda, özellikle işlenmiş bazı yerel ürünlerin pazarda kalkınma aracı olarak kullanılması son dönemlerde önem kazanmaya başlamıştır. Bu bakımdan, yöresel ürünleri ve özelliklerini ortaya çıkarmaya, yerelin özel ürünlerini markalaştırmaya ve katma değerini yükseltmeye yönelik gelir getirici yeni iş alanlarının oluşmasına katkı sağlayacak projelerin desteklenmesi gerekmektedir. Ülkemizde üretilen toplam yaş kırmızı biberin \%47.7'si Şanlıurfa'dan karşılanmaktadır. Bu çalışmanın ana materyalini Şanlıurfa, İstanbul, Ankara, İzmir, Bursa, Adana, Antalya ve Sivas'ta isot biberi satıcıları ile yüz yüze yapılan anketlerden elde edilen veriler oluşturmaktadır. Anketler yatay kesit analizi ile 2015 yılında yapılmıştır. Satıcılar basit tesadüfî örnekleme yöntemiyle seçilmiş ve 351 anket yapılmıştır. Değerlendirmelerde Likert tutum ölçeği ve SPSS paket programı kullanımıştır. Satıcılara göre isot biberinin en önemli sorunları \%73.7 ile pazarlama ve \%72.8 ile tanıtım olarak tespit edilmiştir.
\end{abstract}

Anahtar Kelimeler: İsot biberi, Tarımsal üretim, Pazarlama, Satıcılar

\section{The Situation Of Şanlıurfa Isot Pepper In Marketing Channels: The Sellers Sampling}

\begin{abstract}
The function of the seller is great in manufactured goods from the producers to the consumers. The seller has an important role in the economic structure and the development of marketing channels. It is becoming more important in the marketing of agricultural products, due to productions and consumptions are carried out at different places and times. In agricultural areas, some of the local processed products start to use as a development tool in the market in recent years. In this regard, it is necessary to support local products and reveals the characteristics and add value to a brand. The main material of this research comes from isot pepper sellers of Şanlıurfa, İstanbul, Ankara, İzmir, Bursa, Adana, Antalya and Sivas provinces by given face to face questionnaires and conducted in 2015 . The sellers selected by simple random sampling method and 351 surveys were done. Likert attitude scale and SPSS packet program were used in the evaluations. According to the sellers; the most important problems in isot pepper were marketing by $73.7 \%$ and followed by $72.8 \%$ of promotion.
\end{abstract}

Keywords: İsot pepper, Agricultural production, Marketing, Sellers 


\section{Giriş}

Üreticiler tarafından üretilen mal ve hizmetlerin tüketiciye ulaştırılmasında aracıların ve satıcıların fonksiyonu büyüktür. Aracılar ve satıcılar üretilen malların tüketim, yer, şekil ve zaman faydalarının arttırılmasında, pazarlama kanalında ve ekonomik yapının gelişmesinde önemli bir role sahiptirler. Diğer taraftan pazarlama üretimin devamı özelliğini göstermekte ve üretime yön vermektedir (Güneş, 1996). Bu da günümüzde ağırlıklı olarak aracılar ve satıcılar yoluyla yapılmaktadır. Aracıların ve satıcıların bu fonksiyonu tarımsal ürünlerin pazarlanmasında daha da önemli hale gelmektedir. Çünkü genellikle üretim ile tüketim farklı yerlerde ve zamanlarda yapılmaktadır. Üreticilerin ise doğrudan tüketicilere ulaşabilme imkân ve kabiliyetleri ise kısıtlıdır, aracı ve satıcılar sayesinde üreticiler yerel pazarlar dışındaki pazarlara da kolaylıkla ulaşabilmektedirler (Emeksiz ve ark., 2005). Aracıların ve satıcıların bir diğer önemli rolü de üreticiler ve tüketiciler ile alış ve satış esnasında, yüz yüze bir araya gelmeleri nedeniyle, genel ekonominin, arz ve talep açısından, daha iyi işlemesine hizmet ederler. Tüketici taleplerini, üreticilere fiyat, satış miktarı ve zamanı yoluyla geri bildirim yaparlar. Üreticiler ise bu geri bildirimlere bağlı olarak üretim şekli, çeşidi, özellikleri, miktarı ve zamanı açısından üretim düzenlemesi ve planlaması yaparak kazançlarını arttırma çabasına girerler. Her alışveriş işlemi sayesinde üretici ile tüketici arasında, aracılar ve satıcılar yoluyla, alınacak ve satılacak ürün miktarı ile ödeme şekli ve zamanı, temin biçimi ve değişim koşulları belirlenir ve aracılar değişim sürecinde verimliliği arttırırlar (Anonim, 2016a). Bu yönüyle aracılar ve satıcılar, üretilmiş olan malların ve hizmetlerin zayi olmadan tüketiciye ve kullanıcıya ulaştırmakta, işlenmesinde rol oynamakta, aracılığın uygun kar oranları içinde yapılması ve fiyat ayarlanması ile üretici ve tüketici gelirleri üzerinde ve dolayısıyla ülke ekonomisinde etkili olmaktadır (Güneş, 1996).

Şanlıurfa, tarımsal arazi büyüklüğü ve üretilen bitkisel üretim değerleri bakımından ülkemizin sayılı illerden biri olup, tarım ve tarıma dayalı sanayinin oluşturduğu ekonomik değerler beklendiği faydayı yeteri kadar sağlayamamıştır. Bunun nedenlerinden biri de, Güneydoğu Anadolu Projesi (GAP) ile birlikte bitkisel üretim değerinde meydana gelen artışın imalat sanayisinde değerlendirilerek katma değeri yüksek ürünlere işlenerek dönüştürülememesi ve pazarlanamamasıdır. Bölgede yatırım beklentisi de istenen oranda gerçekleşebilmiş değildir. Diğer taraftan GAP projesinde ön görülen hedefler açısından girişimciliğin gelişmesi son derece önemli olup, birçok sebepten dolayı, yeteri kadar geliştiği de söylenemez (Paksoy ve Aydoğdu, 2010). Bu durum gelir dağılımı ve işsizlikteki beklenen iyileşmenin sağlanamamasında ve bölge içi ve dışı göçlerin devam etmesinde etkili faktörler olmuştur. Bu nedenle, mevcut tarımsal potansiyel ile ilgili fırsatların etkin bir şekilde kullanılması zorunluluktur.

Tarımsal alanda, özellikle işlenmiş bazı yerel ürünlerin ulusal ve/veya uluslararası pazarda kalkınma aracı olarak kullanılması son dönemlerde önem kazanmaya başlamıştır. Bu bakımdan, yöresel ürünleri ve özelliklerini ortaya çıkarmaya, yerelin özel ürünlerini markalaştırmaya ve katma değerini yükseltmeye yönelik gelir getirici yeni iş alanlarının oluşmasına katkı sağlayacak projelerin desteklenmesi gerekmektedir. Kırmızı biber yetiştiriciliği bölge tarımında, alternatif ürün olarak önemli bir potansiyele sahiptir. Ülkemizde 
üretilen toplam yaş kırmızı biberin yarısına yakını Şanlıurfa il sınırlarında yetiştirilmektedir (Çizelge 1). Kırmızı biberi
Bölge için kritik bir ürün haline getiren temel nedenlerin başında, bir baharat olarak kullanılan geleneksel isot biberi gelmektedir.

Çizelge 1. Üretilen yaş kırmızı biber verileri, (TÜiK, 2012; GTHB, 2012)

Table 1. The data of fresh red pepper produced, (TSI, 2012; MFAL, 2012)

\begin{tabular}{lcccc}
\hline & $\begin{array}{c}\text { Kırmızıbiber Ekilen } \\
\text { Alan (Dekar) } \\
\text { Cultivated Red Pepper } \\
\text { Areas (Da) }\end{array}$ & $\begin{array}{c}\text { Üretilen Yaş } \\
\text { Kırmızıbiber (Ton) } \\
\text { Produced Red } \\
\text { Pepper (Ton) }\end{array}$ & $\begin{array}{c}\text { Ortalama Verim } \\
\text { Average Yield }\end{array}$ & $\begin{array}{c}\text { Oran (\%) } \\
\text { Rate (\%) }\end{array}$ \\
\hline Türkiye & 112,677 & 165,527 & 1,469 & 100 \\
GAP Bölgesi & 91,383 & 129,098 & 1,413 & 78.0 \\
Hatay-Kahramanmaraş- & 15,752 & 27,750 & 1,726 & 16.6 \\
Osmaniye & & & & 30.3 \\
Gaziantep-Kilis & 48,550 & 50,154 & 1,033 & 47.7 \\
Şanlıurfa & 42,383 & 78,924 & 1,843 & 4 \\
\hline
\end{tabular}

Bölge de önceleri sadece özel tüketim için elde edilen isot biberi, günümüzde özellikle kadınlar başta olmak üzere, ekonomik seviyesi düşük olan aile grupları için önemli bir gelir kaynağı olarak görülmeye başlanmıştır. Tüketicilerin de daha doğal özelliğe sahip geleneksel ürünlere eğilim göstermeye başlaması, Şanlıurfa isot biberine ulusal ve/veya uluslararası piyasada da pazarlanan bir ürün haline gelebilme imkânı sunmuştur. Ancak markalaşamama, taklit ve tağşiş ürünler nedeniyle pazardan yeteri kadar pay aldığı da söylenemez (Atasoy ve Aydoğdu, 2016). Bu çalışmanın amacı isot biberinin pazarlama kanallarındaki durumu, algısı, potansiyeli, sorunları ve beklentilerin tespitine yönelik olarak, aracıların ve satıcıların bakışlarının belirlenmesidir.

\section{Materyal ve Yöntem}

Bu çalışmanın ana materyalini Şanlıurfa, İstanbul, Ankara, İzmir, Bursa, Adana, Antalya ve Sivas'ta isot biberi satıcıları ile yüz yüze yapılan anketlerden elde edilen veriler oluşturmaktadır. Anketler yatay kesit analizi ile 2015 yılında yapılmıştır. Bu iller nüfus, dolayısıyla tüketici sayısı, bulundukları coğrafi konum ve isotun tüketim özelliklerine bağlı olarak gayeli seçilmiştir. İstanbul, Ankara, İzmir ve Bursa ülkemizin nüfus yönünden en kalabalık ilk dört ili (Tüik, 2015), Şanlıurfa ve Adana isot biberi tüketiminin yaygın olduğu iller, Antalya sıcak iklim kuşağından ve Sivas ise soğuk iklim kuşağından gayeli olarak seçilmiştir. Bu illerdeki ana kitleyi baharatçılar çarşısı, aktarlar ve kuru gıda satıcıları oluşturmaktadır. Ana kitleden, araştırma konusunu temsil kabiliyeti olan ve anket yapmayı kabul eden isot biberi satıcıları ise basit tesadüfî örnekleme yöntemiyle seçilmiştir. Bu kapsamda Şanlıurfa'da 86, diğer illerde ise 265 anket olmak üzere, toplam 351 anket yapılarak, değerlendirmelerde kullanılmıştır.

$\mathrm{Bu}$ çalışmada, SPSS paket programı kullanılmıştır. Anket sorularının cevaplarında yaygın olarak kullanılan beşli Likert tutum ölçeğinden yararlanılmıştır. Temel yaklaşım kişilere araştırılan konuyla ilgili yargıların verilmesi ve bu yargılar üzerinde yoğunlaşmanın bulunması esas alınmıştır. Likert ölçeklerinin istenen sonucu tam olarak verebilmesi için yargıları kapsayan cümlelerin bazı temel özellikleri taşıması gerekir. Yargı 
cümlelerinin tek anlamlı ve kesin sonuçlu olması gerekir. Cümleler ihtimalli sonuçlar ortaya koymamalı, katılımcıda şüphe yaratmamalı, açık ve anlaşııır olmalıdır. Bu ölçek kullanılırken yargı cümleleri kişilere bir düzen içerisinde verilir ve kişinin her bir yargı cümlesi karşısında kendisine uygun görünen seçeneği işaretleyerek katılma derecesini göstermesi istenir. Çalışmanın sonunda her bir yargı cümlesine grubu oluşturan bireylerin katılma derecelerinin sayısal dağııımı saptanır ve katılma seçeneklerinin sayısal değeri ile seçenek katsayısı çarpılarak elde edilen son değere göre sayısal ortalama hesaplanır. Bu ortalama değerler grubun seçenek değeri olarak alınır ve bulunan seçenek değeri ile karşılaştırııı, yargının tutum üzerindeki etkisi saptanır. Likert ölçeklerinde genel olarak \%85 güvenilirlik katsayısı kabul görür (Aydoğdu ve ark., 2015). Ayrıca faktörler arasındaki korelâsyonların ölçülebilmesi içinde SPSS paket programından yararlanılmış olup (Antalyalı, 2010; Küçüksille, 2010), istatistikî olarak anlamlı olanlar parametreler açıklanmıştır. Anketler birden fazla ilde yapıldığından dolayı elde edilen verilerin kendi içinde tutarlılıkların belirlenmesi önemlidir ki, bu da sonuçların güvenilirlik derecesini vermektedir. Bunun için Cronbach alfa katsayısı kullanıı. Eğer bu değer 0.60 'dan büyükse çalışma güvenilir kabul edilir (Özdamar, 1999; Tavşancıl, 2002). Veri setinin Cronbach alfa katsayısı 0.73 olarak tespit edilmiştir. Buna göre bu araştırma güvenilirdir.

\section{Araştırma Bulguları ve Tartışma}

Baharatçılar ve kuru gıda tüketim maddesi satan yerlerden gayeli olarak seçilen satıcılar, ortalama 22.3 yıldır bu işi yaptıklarını belirtmişlerdir. Beyan edilen yıllık ortalama satış miktarları $800.3 \mathrm{~kg}$ olarak hesaplanmıştır. Sektörde yer alma yılları ile satış miktarları arasında anlamlı bir ilişki vardır $(p<0.01)$. Sektördeki hizmet yılı arttıkça, satış miktarı da artmakta olup, bu beklenen bir sonuçtur. iller itibariyle satış yapılan yerlerin dağılımı ve yüzdeleri çizelge 2 'de yer almaktadır. Buna göre en çok satışlar doğrudan tüketicilere, en az satışlar ise marketlere yapılmaktadır. Burada marketlerden kast edilen, ülke genelinde faaliyet gösteren zincir marketler grubu değildir. Zincir marketler grubu, ya büyük baharat üreticilerinden (fabrikalardan) toptan ve büyük miktarlarda alım yapmaktalar, ya da kendi markaları ve gramaj miktarlarına bağı olarak fabrikalarda özel üretim yaptırmaktadırlar. Seçeneklerde yer alan marketler ise mahallî bazda faaliyet gösteren, yerel marketlerdir. En çok satış yapılan yerler ortalaması \%74.6 ile ili içinde olup, sonrada \%15.6 ile bölge içi satışlar, \%7 ile yurtiçi satışlar ve bunlardan bir kaçı ise $\% 2.8^{\prime}$ dir. Satış yapılan yerler ile sektördeki hizmet yılı ve üretim miktarı arasında anlamlı bir ilişki vardır $(p<0.01)$. Hizmet yılı ve satış miktarı arttıkça, satış yapılan yer çeşitlemesi de artmaktadır. İsot biberi siyah ve kırmızı renk olarak üretilebilmektedir. Renk farkı kurutma esnasındaki işlem farklılığından kaynaklanmaktır. Yapılan bir araştırmada geleneksel isotun daha iyi renk kalitesine sahip olduğu belirlenmiştir (Korkmaz ve ark., 2016). 
Çizelge 2. Illere göre satış yapılan yerler ve yüzdeleri

Table 2. Percantages of the places made sale by provinces

\begin{tabular}{lccccc}
\hline $\begin{array}{l}\text { Iller (\%) } \\
\text { Provinces (\%) }\end{array}$ & $\begin{array}{c}\text { Toptancilar } \\
\text { Wholesalers }\end{array}$ & $\begin{array}{c}\text { Perakendeciler } \\
\text { Retailers }\end{array}$ & $\begin{array}{c}\text { Marketler } \\
\text { Markets }\end{array}$ & $\begin{array}{c}\text { Tüketiciler } \\
\text { Consumers }\end{array}$ & $\begin{array}{c}\text { Birden fazla satıs yeri } \\
\text { Multiple sale locations }\end{array}$ \\
\hline Ankara & 0.0 & 2.3 & 0.0 & 81.4 & 16.3 \\
Bursa & 7.5 & 40.0 & 5.0 & 12.5 & 35.0 \\
İzmir & 0.0 & 2.8 & 5.5 & 61.1 & 30.6 \\
Adana & 2.5 & 25.0 & 0.0 & 10.0 & 62.5 \\
Sivas & 0.0 & 7.5 & 0.0 & 75.0 & 17.5 \\
Antalya & 5.0 & 10.0 & 5.0 & 65.0 & 15.0 \\
İstanbul & 3.9 & 11.7 & 0.0 & 50.0 & 34.4 \\
Şanlıurfa & 4.7 & 11.6 & 1.2 & 45.3 & 37.2 \\
\hline Ortalama & 3.0 & 13.9 & 2.1 & 50.0 & 31.0 \\
\hline
\end{tabular}

Satıcıların hangi renk isot biberi daha fazla tercih edilir sorusuna vermiş oldukları cevaplar iller ve yüzdeler itibariyle çizelge 3 'te verilmiştir. Buna göre her iki renk de tercih edilmektedir. Renk tercihleri illere bağlı olarak farklılıklar gösterebilmektedir. Her ilin tüketicisinin isot biberini kullanma amacına bağlı olarak, renk tercihi değişebilmektedir. Diğer taraftan pek çok ilde tüketicinin renk konusunda çok fazla seçici olarak davrandıkları da söylenemez. Bu illerin tüketicileri isotu daha çok baharat olarak kullanmaktadırlar.

Çizelge 3. Hangi renk isot biberi daha fazla tercih edilmektedir?

Table 3. Which color isot pepper is more preferred?

\begin{tabular}{lccc}
\hline $\begin{array}{l}\text { iller (\%) } \\
\text { Provinces (\%) }\end{array}$ & $\begin{array}{c}\text { Siyah renk } \\
\text { Black color }\end{array}$ & $\begin{array}{c}\text { Kırmızı renk } \\
\text { Red color }\end{array}$ & $\begin{array}{c}\text { Her ikisi de } \\
\text { Both of them }\end{array}$ \\
\hline Ankara & 14.0 & 60.5 & 25.5 \\
Bursa & 22.5 & 40.0 & 37.5 \\
İzmir & 38.9 & 2.8 & 58.3 \\
Adana & 10.0 & 0.0 & 90.0 \\
Sivas & 47.5 & 7.5 & 45.0 \\
Antalya & 80.0 & 2.5 & 17.5 \\
İstanbul & 57.7 & 7.7 & 34.6 \\
Şanlıurfa & 33.1 & 8.1 & 58.8 \\
\hline Ortalama Average & 38.0 & 16.1 & 45.9 \\
\hline
\end{tabular}

Satıcılar ortalamasına göre isot $\% 43.8$ oranında açıkta torbadan, $\% 14$ oranında kutu ambalaj ile ve \%42.2 oranında ise her iki şekilde satılmaktadır. İsot biberi, Ankara'da \%37.2, Bursa'da ise \%32.5 oranında kutu ambalaj ile satılırken, bu oran Adana'da \%2.5 ve Şanlıurfa'da ise \%2.3 olarak tespit edilmiştir. Bu durum illere bağlı olarak farklılıklar gösterebilmekle birlikte, beklenen bir sonuç olup, isota olan algı, satışı yapan yer, güven ve kullanım şekline göre farklılık gösterebilmektedir. Satıcılar ortalamasına göre isot biberi \%23.5 oranında $100 \mathrm{gr}$, \%22.2 oranında $250 \mathrm{gr}$, \%23.1 oranında 500 gr ve \%31.2 oranında ise daha fazla gramajı olarak satılmaktadır. Satış miktarları illere göre büyük farklılıklar göstermektedir. İsot biberini yemek kültürü ve geleneksel tat olarak kullananlar, Şanlıurfa ve Adana gibi, daha büyük gramajlarla satın almaktadırlar ( $p<0.05$ ). Büyük şehirlerde ise isot genellikle baharat olarak tercih edilmektedir. 
Dolayısıyla kullanım miktarlarına bağlı olarak, hane halkı sayısı, tüketim amacı ve miktarı, satın alınan gramajı belirlemektedir $(p<0.01)$.

Satıcılara göre isot biberi sektörünün en önemli sorunu \%79.7 ile fiyat yetersizliği, \%74 ile gıda güvenliği sertifikası olmaması, \%71 ile markası ve marka değerinin verdiği güven olarak tespit edilmiştir. İsot biberi üreticilerinin sorunlarını belirlemek için yapılan bir çalışmada da üreticilerin mevcut fiyatları yetersiz buldukları tespit edilmiştir (Aydoğdu ve ark., 2016a). Bir mal için pazarda satış için belirlenen fiyat, birim kar marjını etkiler. Birçok küçük işletme fiyatı rekabet etmek, sektörde kalabilmek, pazar payını değiştirmek ve farklı gelir senaryoları oluşturmak için kullanır. Fiyat, üretilmiş olan mal ve hizmetlere, pazarda arz cephesi tarafından beklentilerine uygun değerin biçilmesidir. Diğer taraftan da bu değerin talep cephesinde karşılık bulması gereklidir $\mathrm{ki}$, alışveriş olsun. Fiyat, malın pazarda marka, imaj ve konumu belirler (Edmunds, 2016). Teknolojik gelişme, ekonomik ve sosyal refahın artması tüketicilerin gıda tüketimi üzerine olan hassasiyetini arttırmış ve satın alma davranışlarını değiştirmiştir. Tokat ilinde yapılan bir çalışmada tüketicilerin \%75.8 gibi önemli bir kısmı, güvenilir gıda için fazladan ödeme yapmaya razı oldukları belirlenmiştir (Onurlubaş, 2011). Sanayileşme ve artan nüfusa bağlı olarak birim alandan daha fazla ürün elde edebilmek için, üretimde çeşitli kimyasallar yaygın olarak kullanılmaktadır. Bu kimyasalların sağlık yönünden olası etkileri tüketicileri daha bilinçli tercih yapmaya zorlamaktadır. Geleneksel olarak üretilmiş ve doğal ürünlere artan bir yönelim olmakla beraber, tüketicilerin geleneksel gıdalarda gıda güvenliği algıları da oldukça önemli hale gelmektedir (Taşdan ve ark., 2014). Tüketicilerin yöresel isot biberi alım miktarında en önemli faktörlerden biri de gıda güvenliği sertifikası olarak belirlenmiştir (Aydoğdu ve ark., 2016b). Bir mal veya hizmetin pazarlanabilmesi için bir markası ve değerinin olması gereklidir. Bu markanın sürekliliğinin olabilmesi için de tüketicisi ile duygusal bir bağ oluşturması lazımdır. Tüketici bilmediği, sevmediği ve güvenmediği bir markaya duygusal olarak bağlanmaz (VanAuken, 2015). Satıcılara göre isot biberi sektörünün en önemsiz sorunu da \%46 ile gramaj ve miktar olmuştur. Satıcılara göre isotun gramaj ve miktarı satış esnasında sorun teşkil edecek bir durum değildir $(p<0.05)$. Çünkü satışlar ağırlıklı olarak, talep edilen miktarlar için açıkta torbalardan yapılmaktadır.

Renk, koku, görünüş ve tadın algılanması bilişsel olup, tüketicilerin gıda ürününe yönelik ilk reaksiyonunu belirler, koku ve tat lezzeti oluşturur (Anonim, 2016b). Buda bireylerin kültürüne ve edindikleri deneyimlere göre faklılıklar göstermektedir. İsot biberinin alımında tüketici algılarının alım miktarını etkileme oranı \%35.6 olarak ölçülmüştür (Aydoğdu ve ark., 2016b). Satıcılara isot biberi alan tüketiciler en çok neye dikkat eder soru faktörlü olarak sorulmuş ve sıralama yapmaları istenmiştir. Alınan cevaplar ve önem yüzdeleri çizelge 4'de yer almaktadır. Elde edilen sonuçlara göre iller arasında anlamlı farklılıklar mevcuttur. Renk en önemli faktör olarak belirlenmiştir. Mesela renk tercihleri Şanlıurfa ve Adana için \%96 ve \%91oranında önemli iken, Bursa ve Sivas için bu oranlar $\% 53$ ve \%46 civarındadır. Diğer taraftan hijyen ortalama faktör sıralamasında en üst sırada yer almamış olup, beklenmeyen bir sonuçtur. Bu oran izzmir de en yüksek çıkmıştır, bu beklenen bir sonuçtur. Diğer taraftan Şanlıurfa'da da yüksek çıkmıştır, bu da beklenmeyen bir sonuçtur. 
Çizelge 4. İsot biberi alanlar en çok neye dikkat ederler

Table 4. Which the consumers who bought isot pepper be careful the best

\begin{tabular}{|c|c|c|c|c|c|c|c|c|c|}
\hline $\begin{array}{l}\text { iller } \\
\text { Provinces }\end{array}$ & Ankara & Bursa & İzmir & Adana & Sivas & Antalya & İstanbul & Ş.Urfa & $\begin{array}{l}\text { Ortalama } \\
\text { Average }\end{array}$ \\
\hline $\begin{array}{l}\text { Faktörler } \\
\text { Factors }\end{array}$ & $\%$ & $\%$ & $\%$ & $\%$ & $\%$ & $\%$ & $\%$ & $\%$ & $\%$ \\
\hline $\begin{array}{l}\text { Renk } \\
\text { Color }\end{array}$ & 64.5 & 53.2 & 87.3 & 90.7 & 45.7 & 76.8 & 77.7 & 96.0 & 74.0 \\
\hline $\begin{array}{l}\text { Görünüş } \\
\text { Appereance }\end{array}$ & 74.8 & 62.2 & 95.6 & 64.6 & 53.2 & 49.6 & 51.4 & 91.9 & 67.9 \\
\hline $\begin{array}{l}\text { Hijyen şartları } \\
\text { Hygiene status }\end{array}$ & 67.4 & 68.2 & 96.0 & 43.2 & 75.7 & 53.7 & 55.4 & 89.4 & 68.7 \\
\hline $\begin{array}{l}\text { Tat } \\
\text { Taste }\end{array}$ & 36.5 & 74.3 & 98.3 & 46.8 & 67.5 & 65.0 & 61.7 & 95.8 & 68.3 \\
\hline $\begin{array}{l}\text { Acılık } \\
\text { Bitterness }\end{array}$ & 71.8 & 52.1 & 96.7 & 49.3 & 66.1 & 57.5 & 49.2 & 90.2 & 66.6 \\
\hline
\end{tabular}

Bunun nedenlerini belirlemek için anket yapılan satıcıların bazıları tekrar ziyaret edilmiştir. Satıcılar, genellikle tüketicilerin isot biberini bildikleri ve tanıdıkları yerlerden, açıkta ve torbadan, güvene dayalı olarak aldıklarını ifade etmişlerdir. Şanlıurfa'daki satıcılar ise büyük miktarda tüketim yapanların isot biberini, üretim sezonunda, yaz aylarında, düşük gelir grubunda yer alan tanıdıkları ve güvendikleri ailelerden doğrudan temin ettiklerini, üretim sezonu dışındaki alımlarında ise hijyene önem verdiklerini belirtmişlerdir. Çizelge 4 'te yer alan faktörler ortalama değerler açısından homojen olarak görünseler de, faktörlerin illere göre dağılımı heterojendir. $\mathrm{Bu}$ da illerdeki tüketicilerin isot biberini kullanma amacı ve farklı sosyo-ekonomik yapıda olmalarının bir sonucudur.

Fiyat gelir ile ilgili olup, üretici, aracı ve tüketici açısından ise önemli bir değişkendir. Bir mal veya hizmetin fiyatının yüksek ve düşük olmasının tüketiciler üzerinde farklı etkileri vardır. Düşük bir fiyatla pazara sunumu yapılan bir mal genellikle tüketicide kalite ve güven konusunda şüphe uyandırır. Yüksek bir fiyat ise kalite ve güven duygusu verirken, tüketim ve alım miktarını azaltır. Diğer taraftan her yüksek fiyatla satılan mal ve hizmetler ise mutlaka kaliteli demek de değildir. Her iki durumda da arz cephesi, yani üreticiler ve satıcılar olumsuz yönde etkilenir. Pazarda doğru fiyatın oluşturulması bu açıdan çok önemlidir. Satıcıların piyasada kaliteli ve normal isot biberi kaça satılmalıdır soruna vermiş oldukları cevaplar ortalaması çizelge 5'de yer almaktadır. Burada da illere bağlı olarak faklı sonuçlar elde edilmiştir. Yani satıcıların fiyat beklentileri arasında önemli farklıklar vardır. Şanlıurfa'da normal isot biberi 10-15 TL, kaliteli isot biberi ise 3050 TL arasında bir fiyatla satılmaktadır. Burada kaliteyi belirleyen unsurlar arasında kurutma da kullanılan kırmızıbiberin cinsi, kalitesi, üretildiği yer, işleme yöntemi ve isot biberi içindeki tohum miktarı belirleyici olmaktadır. 
Çizelge 5. İsot biberi kaç liraya satılmalıdır?

Table 5. How much money (TL) isot peper should be sold?

\begin{tabular}{|c|c|c|c|c|c|c|c|c|c|}
\hline $\begin{array}{l}\text { illler } \\
\text { Provinces }\end{array}$ & Ankara & Bursa & İzmir & Adana & Sivas & Antalya & İstanbul & Şanlıurfa & $\begin{array}{c}\text { Ortalama } \\
\text { Average }\end{array}$ \\
\hline $\begin{array}{l}\text { Kaliteli } \\
\text { Qualified }\end{array}$ & 35.35 & 31.13 & 23.94 & 40.95 & 28.45 & 31.13 & 55.88 & 28.55 & 34.42 \\
\hline $\begin{array}{l}\text { Normal } \\
\text { Normal }\end{array}$ & 24.54 & 15.88 & 11.31 & 21.88 & 16.38 & 14.08 & 22.80 & 12.28 & 17.39 \\
\hline
\end{tabular}

Satıcılara isot sektörüne ilişkin en önemli sorunların neler olarak görüldüğünü belirlemek üzere hazırlanan soru seçenekli olarak sorulmuş ve değerlendirmeleri istenmiştir. Verilen cevaplar çizelge 6 'da yer almaktadır. Buna göre sektörün en önemli sorunları $\% 73.7$ ile pazarlama ve $\% 72.8$ ile

Çizelge 6. Satıcılara göre isot sektörünün sorunları Table 6. The problems of the isot sector temper to the seller

\begin{tabular}{|c|c|c|c|c|c|c|c|c|c|}
\hline $\begin{array}{l}\text { Faktörler (\%) } \\
\text { Factors (\%) }\end{array}$ & Adana & Ankara & Antalya & Bursa & İstanbul & İzmir & Sivas & Ş.Urfa & $\begin{array}{c}\text { Ortalama } \\
\text { Average }\end{array}$ \\
\hline $\begin{array}{l}\text { Pazar yetersizliği } \\
\text { Market inadequacy }\end{array}$ & 73.6 & 61.8 & 67.5 & 31.8 & 57.2 & 77.8 & 67.9 & 79.4 & 64.6 \\
\hline $\begin{array}{l}\text { Pazarlama } \\
\text { Marketing }\end{array}$ & 67.5 & 79.7 & 64.7 & 62.2 & 68.0 & 93.7 & 69.7 & 84.0 & 73.7 \\
\hline $\begin{array}{l}\text { Markalaşamama } \\
\text { Branding inability }\end{array}$ & 49.7 & 69.5 & 57.9 & 59.3 & 63.4 & 92.5 & 54.7 & 77.9 & 65.6 \\
\hline $\begin{array}{l}\text { Tanıtım } \\
\text { Promotoin }\end{array}$ & 51.4 & 85.1 & 72.9 & 66.8 & 65.7 & 94.4 & 65.0 & 80.8 & 72.8 \\
\hline $\begin{array}{l}\text { Taklit ürünler } \\
\text { Counterfeit goods }\end{array}$ & 66.8 & 25.3 & 48.9 & 88.6 & 51.4 & 94.8 & 44.0 & 87.9 & 63.5 \\
\hline
\end{tabular}

Satıcıların isota yönelik olarak algı ve tutumlarını belirlemek üzere oluşturulan faktörlere ilişkin katılımları ölçülmüştür. Buna göre en yüksek katılım isotun tadına, tanıtımdır. Tanıtım olmadan pazarlama olamaz. Tanıtım ürün sunumlarında ilgili ve potansiyel tüketiciler ile iletişim kurulmak için yapılır, karlılık ve pazarlama başarısını belirlemede önemli bir role sahiptir (Rowley, 1998). en düşük katılım ise isotun gramajına olmuştur. Cevaplar ve katılma oranları çizelge 7'de yer almaktadır. 
Çizelge 7. Satııların isota yönelik faktörlere katılım oranları

Table 7. The participation rates of the sellers to the factors intended for isot pepper

\begin{tabular}{|c|c|c|c|c|c|c|c|c|c|}
\hline $\begin{array}{l}\text { Faktörler } \% \\
\text { Factors of Isot \% }\end{array}$ & Adana & Ankara & Antalya & Bursa & İstanbul & İzmir & Sivas & Ş.Urfa & $\begin{array}{c}\text { Ortalama } \\
\text { Average }\end{array}$ \\
\hline İsot da renk önemlidir & 94.0 & 76.8 & 96.0 & 79.0 & 82.4 & 80.6 & 76.0 & 89.1 & 84.3 \\
\hline $\begin{array}{l}\text { Color is important } \\
\text { İsotun kokusu önemlidir } \\
\text { Smell is important }\end{array}$ & 76.5 & 60.5 & 93.0 & 71.5 & 87.2 & 92.8 & 84.0 & 92.1 & 82.2 \\
\hline $\begin{array}{l}\text { İsotun tadı çok önemlidir } \\
\text { Taste is very important }\end{array}$ & 94.0 & 73.0 & 92.5 & 81.0 & 90.4 & 92.8 & 92.5 & 97.7 & 89.2 \\
\hline $\begin{array}{l}\text { Urfa isotu acıdır } \\
\text { Urfa isot pepper is bitter }\end{array}$ & 59.0 & 94.9 & 90.5 & 77.0 & 75.2 & 81.1 & 88.0 & 83.7 & 81.2 \\
\hline $\begin{array}{l}\text { İsot en çok çiğköfte de } \\
\text { kullanılır } \\
\text { Mostly used at çiğköfte }\end{array}$ & 73.0 & 73.0 & 84.5 & 55.5 & 82.4 & 81.1 & 78.5 & 78.8 & 75.9 \\
\hline $\begin{array}{l}\text { Üretildiği il önemlidir } \\
\text { Production place is } \\
\text { important }\end{array}$ & 92.0 & 82.3 & 86.0 & 75.5 & 81.6 & 92.2 & 77.5 & 91.9 & 84.9 \\
\hline $\begin{array}{l}\text { İsotta gıda güvenliği } \\
\text { önemlidir }\end{array}$ & 54.0 & 70.3 & 93.0 & 84.5 & 70.4 & 78.3 & 85.0 & 92.8 & 78.6 \\
\hline Food safety is important & & & & & & & & & \\
\hline $\begin{array}{l}\text { Gramajı önemlidir } \\
\text { Weight is important }\end{array}$ & 56.5 & 66.5 & 82.5 & 63.0 & 72.0 & 91.1 & 61.5 & 62.1 & 69.4 \\
\hline Kaliteli isot pahalıdır & 74.0 & 82.3 & 84.0 & 68.0 & 82.4 & 86.1 & 77.0 & 94.0 & 70.5 \\
\hline $\begin{array}{l}\text { Qualified one is } \\
\text { expensive }\end{array}$ & & & & & & & & & \\
\hline $\begin{array}{l}\text { Pazar değil pazarlama } \\
\text { problemi vardır } \\
\text { Marketing problem exist } \\
\text { rather then market }\end{array}$ & 85.0 & 95.8 & 84.0 & 78.0 & 80.0 & 86.6 & 85.5 & 83.7 & 84.8 \\
\hline $\begin{array}{l}\text { Urfa isot biberi } \\
\text { markalaşamamıştır } \\
\text { Inability of branding }\end{array}$ & 84.5 & 94.0 & 78.5 & 55.5 & 81.6 & 81.1 & 88.0 & 75.6 & 79.9 \\
\hline
\end{tabular}

\section{Sonuçlar}

$\mathrm{Bu}$ araştırmanın en önemli sonucu isot biberine olan algının illere bağı olarak çok büyük farklılıklar göstermesidir. Yani isot biberi, özellikleri, kullanım yerleri ve amaçları açısından yeterince bilinmemektedir. Bu açıdan kullanım miktarı ve verilen önem farklılıklar göstermektedir. Bunun içinde tanıtım yapılması gereklidir. Tanıtım olmadan, pazarlama olamaz. Tüketici davranışları, tüketim miktarı üzerinde oldukça etkilidir. Buda üretim miktarını ve üreticileri doğrudan ilgilendirmektedir. Tüketicilerin algıları, beklentileri ve tutumları, aracı ve satıcılar yoluyla, üreticilere iletilmektedir. Bunun temel göstergeleri arasında ise fiyat ile satış miktarları yer almaktadır. Bir mal ya da hizmetin pazarda var olabilmesi için tüketiciler açısından; farkındalık oluşturması, ilgi farklılaşmasını sağlaması, değerli ve erişilebilir olması lazımdır.

İsot biberinde pazarlama problemi vardır. Pazarlama probleminin temel unsurlarından birileri de markalaşma ve tanıtımdır. Her ne kadar bu çalışmada markalaşamama sektörün önemli sorunları arasında ilk sıralarda yer alamamışsa da, ortadaki gerçek Şanlıurfa isot biberi markalaşamamıştır. Markalaşmanın, ürüne olan talebin oluşturulması, aracılara doğru ürünü 
çekmesi, pazara sunumunda avantaj sağlaması, ürüne bağlılık kazandırması, siparişlerin izlenmesini ve işlenmesini kolaylaştırması ve haksız rekabetten koruma gibi faydaları vardır (Çağlar ve Kılıç, 2005). Diğer taraftan sektörün önemli sorunlarından biri olarak gösterilen tanıtım ise markalaşma ile doğrudan ilgilidir. Pazarlamada, iyi ve kaliteli bir ürün oluşturma, hedef pazarların ve dağıtım kanallarının belirlenmesi karlılık açısından gerekli ancak yeterli değildir. Çünkü tüketicilerin ürünlerin varlığından, sağladığı faydalardan ve avantajlarından haberdar olmaları gereklidir. Buda ancak tanıtım yoluyla olacaktır. Diğer taraftan isot biberine olan yanlış ön yargıların değiştirilmesinde de tanıtım önemlidir. Mesela isot biberinin acı olarak algılanması gibi, bu oran Ankara'daki satıcılarda \%95, Antalya'da \%91 ve Sivas'ta \%88 çıkmıştır. İsotun en çok çiğ köftede kullanıldığına olan algı, Antalya'da \%85, İstanbul'da \%82 ve İzmir'de ise \%81 olarak tespit edilmiştir. Bu algılar isot biberinin kullanım alanını daraltmaktadır. Hâlbuki isot biberi değişik acılıkta ve renkte üretilebilmekte, kahvaltı ve yemeklerde kullanılabilmektedir.

Küresel olarak sağlık, organik ve doğal hayat eğilimleri artmaktadır. Buda yerelleşme eğiliminde artış ve geleneksel gıda ürünlerine giderek artan bir tüketim talebi oluşturmaktadır (Taşdan ve ark., 2014). Bu talebin doğru karşılık bulabilmesi içinde, arz cephesinin, bu beklentilere uygun ürünler ve çeşitler sunması gereklidir. Bu talep iller arasında farklılıklar gösterebilmektedir. Buna uygun ürün çeşitlemesi yapılabilir. Bu çalışmada isot biberinin pazar potansiyelinin arttırılmasına yönelik olarak, satıcı ve aracıların bakışları belirlenmiştir. Bu çalışma bu yönüyle bir ilktir.

\section{Ekler}

Bu çalışma Harran Üniversitesi Bilimsel Araştırma Komisyonu (HÜBAK) (proje NO:14010) ve Türkiye Cumhuriyeti Kalkınma Bakanlığı Güneydoğu Anadolu Projesi Bölge Kalkınma İdaresi Başkanlığı (GAP-ISOT) tarafından desteklenmiştir.

\section{Kaynaklar}

Anonim, 2016a. Pazarlama kanalında aracılar ve önemi. http://notoku.com/pazarlamakanalinda-aracilar-ve-onemi/\#ixzz46Ua5 Pqmm Erişim tarihi: 21.04.2016

Anonim, 2016b. Food sensory and evaluation scales. https://docs.google.com/presen tation/d/1KBx8_1cmbp-nKapjYMkJdScL BDCURNxIx2XL80XfS8/edit?pref=2\&pli Erişim tarihi: 25.04.2016

Antalyalı, Ö. L., 2010. Varyans Analysis, SPSS Applied Multivariate Statistical Techniques. Edt. Şeref Kalaycı, Asil Yayın Dağıtım 5. Baskı, Ankara, 133-134s.

Atasoy, F., Aydoğdu, M.H., 2016. Geleneksel Urfa İsot Biberinin Özelliklerinin Belirlenerek Pazar Potansiyelinin Artırılması Projesi, Kalkınma Bakanlığı, GAP Bölge Kalkınma İdaresi Başkanlığı, Şanlıurfa

Aydoğdu M.H., Yenigün K., Aydoğdu M., 2015. Factors Affecting Farmers' Satisfaction from Water Users Association in Harran Plain-GAP Region, Turkey. Journal of Agricultural Science and Techology, 17(Supplementary issue):1669-1684

Aydoğdu, M. H., Atasoy, A.F., Eren, M.E., Mutlu, N., 2016b. The Consumers' Behaviors Towards To A Regional Food Product In Turkey. IOSR Journal of Agriculture and Veterinary Science, 9(5):25-30. DOI: 10.9790/2380-0905022530

Aydoğdu, M. H., Atasoy, A.F., Eren, M.E., Mutlu, N., Korkmaz, A., 2016a. The Evaluation of the Producers' View towards a Local Agricultural Food Product for Marketing; Isot Pepper of Sanliurfa-GAP, Turkey. IOSR Journal of Environmental Science, Toxicology and Food Technology, 10(9):5964. DOI:10.9790/2402-1009015964

Çağlar, I.., Kılıç, S., 2005. Pazarlama. Nobel Yayın ve Dağıtım, Ankara, 127-147s. 
Edmunds, S.A., 2016. Importance of pricing in business.http://smallbusiness.chron.com /importance-pricing-business-57904. html Erişim tarihi: 25.04.2016

Emeksiz F., Albayrak M., Güneş E., Özçelik A., Özer O. O., Taşdan K., 2005. Türkiye'de tarımsal ürünlerin pazarlama kanalları ve aracıların değerlendirilmesi. http://www.zmo.org.tr/resimler/ekler/7 968ad196a5085f_ek.pdf Erişim tarihi: 21.04.2016

GTHB, 2012. Şanlıurfa'da Kırmızıbiber üretim istatistikleri. Gıda Tarım ve Hayvancılık Bakanlığı verileri, Ankara.

Güneş, T., 1996. Tarımsal Pazarlama, Ankara Üniversitesi, Ziraat Fakültesi Yayınları No: 1467, Ankara, 1s.

Korkmaz, A., Aydoğdu, M.H., Mutlu, N., Atasoy, A.F. 2016. Geleneksel ve Fabrikasyon Yöntemiyle Üretilen İsot Baharatlarının Bazı Fizikokimyasal ve Renk Özelliklerinin Belirlenmesi. Harran Tarım ve Gıda Bilimleri Dergisi, 20(3):204-213.

Küçüksille, E., 2010. Simple Linear Regression, SPSS Applied Multivariate Statistical Techniques. Edt. Şeref Kalaycı, Asil Yayın Dağıtım, 5. Baskı, Ankara, 199s.

Onurlubaş, E., 2011. Tüketicilerin Gıda Güvenliği Konusunda Bilinç Düzeylerinin Ölçülmesi:Tokat îli Örneği. Gaziosmanpaşa Üniversitesi Fen Bilimleri Enstitüsü Tarım Ekonomisi Anabilim Dalı. Doktora Tezi.

Özdamar, E., 1999. Data Analysis and Statistical Package Programs I. Kaan Kitapevi, Eskişehir, 522s.

Paksoy, S., Aydoğdu M.H., 2010. Bölgesel kalkınmada girişimciliğin geliştirilmesi: GAP-GIDEM Örnekleri, Girişimcilik ve Kalkınma Dergisi, 5(1):113-134.

Rowley, J., 1998. Promotion and marketing communications in the information marketplace. Library Review, 47(8), 383387.

Taşdan, K., Albayrak, M., Gürer, B., Özer, O.O., Albayrak, K., Güldal, H.T., 2014. Geleneksel Gıdalarda Tüketicilerin Gıda Güvenliği Algısı: Ankara İli Örneği. Davraz Kongresi, Sözlü Bildiri http://yucita.org/uploads/yayinlar/diger/ makale/Geleneksel_Gdalarda_Tuketicileri n_Gda_Guvenlii_Algs.pdf Erişim tarihi: 25.04.2016

Tavşancıl, E., 2002. Measurement of attitudes and SPSS Data Analysis. Nobel Yayınları, Ankara, 29s.
TÜiK, 2012. Taze Kırmızıbiber Üretim istatistikleri. Türkiye İstatistik Kurumu verileri.

Tüik, 2015. Illere ve ilçelere göre nüfus dağılımları. Türkiye İstatistik Kurumu verileri.

VanAuken, B., 2015. How brand makes emotional connections. The blake project. http://www.brandingstrategyinsider.com/ 2015/09/how-brands-make-emotion alconnections.html\#.Vx57LtKLTMw.Erişim tarihi: 25.04.2016 